\title{
Abnormal Pigmentation
}

National Cancer Institute

\section{Source}

National Cancer Institute. Abnormal Pigmentation. NCI Thesaurus. Code C34930.

An abnormality in the formation or distribution of pigment in the skin, hair or nails. 